\title{
Development of Starch Biofilms Using Different Carboxylic Acids as Plasticizers
}

\author{
Luana Conceição da Cruz ${ }^{a}$, Cleidiene Souza de Miranda ${ }^{a}$,Wilton Jesus dos Santos ${ }^{a}$, \\ Ana Paula Bispo Gonçalves ${ }^{a}$, Jamerson Carneiro de Oliveira ${ }^{a}$, Nadia Mamede José ${ }^{a}$ \\ ${ }^{a}$ Programa de Pós-graduação de Engenharia Química, Instituto de Química, \\ Universidade Federal da Bahia - UFBA, Campus de Ondina, Rua Barão de Jeremoabo, 147, \\ CEP 40170-290, Salvador, BA, Brasil
}

Received: December 15, 2015; Revised: November 11, 2015

\begin{abstract}
Biodegradable films are widely exploited among scientists nowadays. Their positive environmental impact, besides their potential to promote better food conservation and an increase in shelf life motivate research in this field. Availability, low cost and biodegradability of starch increase the interest of using this material to produce biodegradable films. However, starch films tend to be brittle and they need addition of a plasticizer to enable their usage. In this work, starch films were synthesized with different carboxylic acids as plasticizers, aiming to observe the effect of the acids' chain size in the final films properties. Oxalic, succinic and adipic acids were used. The materials were produced by casting and characterized by DSC, TG, XRD, FTIR and SEM. It was observed that the acids chain size influenced on the thermal and structural properties of the films.
\end{abstract}

Keywords: starch, plasticizer, properties, carboxylic acids

\section{Introduction}

Plastics have been increasingly used in our daily lives in various types of products: bottles, containers, cars, etc. Several possibilities have been considered to minimize the environmental impact of conventional polymers. An important alternative is the use of biodegradable polymers, which can be degraded by microorganisms such as bacteria, fungi or algae. Natural additives such as starch, cellulose and lignin are used in conventional formulations of the plastics ${ }^{1}$. Starch is an abundant raw material which allows the development of recyclable products. When this material is biodegraded or incinerated releases $\mathrm{CO}_{2}$ into the atmosphere. This starch characteristic has attracted a strong interest in conventional polymer market by incorporating it in polymer mixtures ${ }^{2}$. In addition, the use of starch is an excellent alternative for edible films and coatings due to its easy processing, low cost, abundance, biodegradability and edibility ${ }^{3-7}$.

The plasticizers are generally, small and low volatile molecules. They are added to polymeric films to improve the processability and increase flexibility. The amount and type of plasticizer employed in starch films influence the functional properties of the starch films ${ }^{8,9}$. These molecules interact with the polymer chain through intra and intermolecular forces (hydrogen bonds), reduce the stiffness of the film and reduce the viscosity of the system. Plasticizers do not alter the structure of the material; however they make it possible to increase the free volume of the polymer chains ${ }^{10,11}$.

Carboxylic acids have great ease of forming hydrogen bonds through its $\mathrm{COOH}$ group. The oxalic, succinic and adipic acids are acids that have different sizes in their carbon chain; a chain of two, four and six carbons respectively ${ }^{11}$. This study aims to evaluate whether the size of carbon chains

*e-mail: luanaconceicaocruz@gmail.com of oxalic, succinic and adipic acids influences the chemical properties of flexible thermoplastic starch films ${ }^{11-13}$.

\section{Material and Methods}

\subsection{Materials}

Corn starch was donated by Cargill Agrícola S.A. (Porto Ferreira, Brazil). The other reagents employed in this study were: oxalic acid (MERK), adipic acid (dynamics) and succinic acid (VETEC).

\subsection{Methods}

\subsubsection{Biofilms preparation}

Flexible films formed by corn starch and various plasticizers as oxalic acid, adipic acid and succinic acid have been developed through the casting process. The gel formed was put in an oven at $40{ }^{\circ} \mathrm{C}$ for $18 \mathrm{~h}$ for drying. A formulation of $5 \%$ acid in the total dry matter (acid and starch) was used. The codes of the formulations are: Oxa 5\%, Adip 5\% and Suc 5\%.

\subsection{Characterization}

DSC analyzes were performed in EXSTAR, model DSC-6220, all samples were analyzed between $25^{\circ} \mathrm{C}$ and $600{ }^{\circ} \mathrm{C}$ with a heating rate of $20^{\circ} \mathrm{C} \mathrm{min}^{-1}$. The thermogravimetric behavior of the materials was analyzed in a thermobalance Shimadzu, Model TGA-50, between $25^{\circ} \mathrm{C}$ to $1000{ }^{\circ} \mathrm{C}$ at a rate of

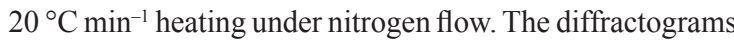
were obtained on Shimadzu X-ray diffractometer model XRD-6000, operating with $\mathrm{CuK} \alpha$ radiation $(\lambda=1.548 \AA)$ with $30 \mathrm{kV}$ and $20 \mathrm{~mA}$ current, using samples in the form of 
powder. The tests were carried out at ambient temperature $\left(25^{\circ} \mathrm{C}\right)$ and with angles $2 \theta$ between 5 and $50^{\circ}\left(2^{\circ} \mathrm{min}^{-1}\right)$. The spectrometer used was a Shimadzu model IR Prestige-21, using the ATR. Scanning Electron Microscope JEOL 6390LV was used to analyze the surface. All samples were coated with gold, using injection of argon.

\section{Results and Discussion}

Figure 1 shows the thermogravimetric curves for pure materials and biofilms. It is observed that the starch is more thermal resistant than pure carboxylic acids. Among the acids, adipic acid showed the highest thermal resistance. By analyzing the DTG curves, starch had two events, the first referring to moisture and the second referring to its degradation. Adipic acid showed a single event with a maximum around $282^{\circ} \mathrm{C}$ related to its degradation, succinic acid had also two events with maxima around 188 and $252^{\circ} \mathrm{C}$ related to their degradation and oxalic acid presented two events, the first related to moisture and the second referring to its degradation.

Figure 1c shows the thermogravimetric curves of biofilms. It was observed that the film containing adipic acid as a plasticizer had higher thermal stability due the higher

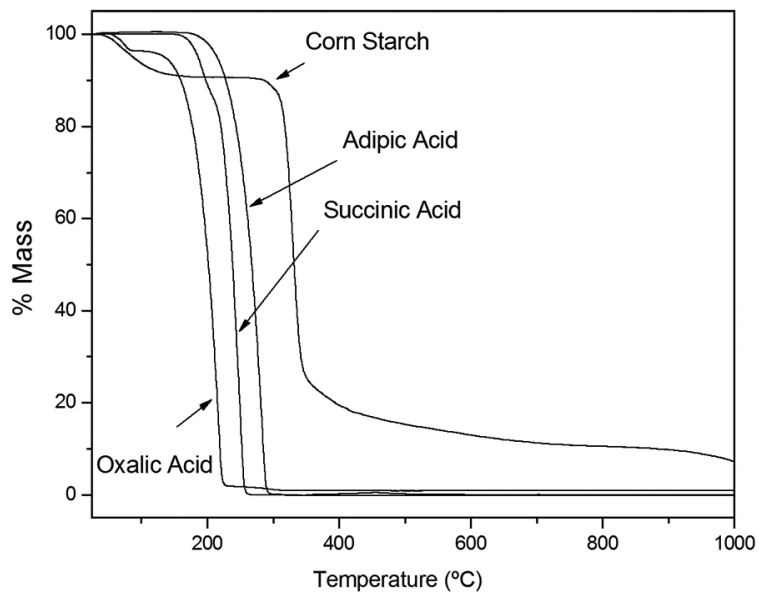

(a)

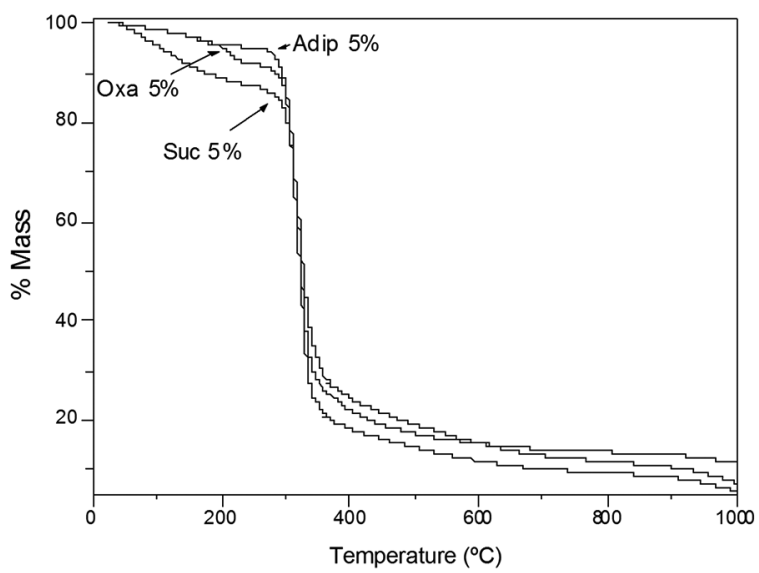

(c) thermal resistance of the acid itself, when compared to the other acids. By analyzing the DTG curves of biofilms only one single event, related to the film degradation, occurred. Small changes were observed in the maximum temperature of degradation, when compared to the maximum temperature of the starch, indicating a possible interaction between the acids and corn starch. Figure 2 shows the DSC curves of the precursors and biofilms. By analyzing the curves of the precursor, events regarding to the melt temperature and degradation of materials were observed. These degradation events corroborate the results found in DTG curves. According to the literature, it is possible to analyze the miscibility of materials evaluating the displacement of the glass and melting temperatures of the precursors in the films. It was observed in all films a displacement of melting and degradation temperature. The film plasticized with succinic acid showed better miscibility due to the lower degradation temperature obtained, when compared to the other films. Therefore, we can infer a likely interaction of starch with all carboxylic acids and that this interaction is more significant in the film containing succinic acid.

Figure 3 shows the XRD diffraction patterns of pure acids and biofilms. According to the crystallinity of the carboxylic acid used as plasticizer, it could be observed structural changes

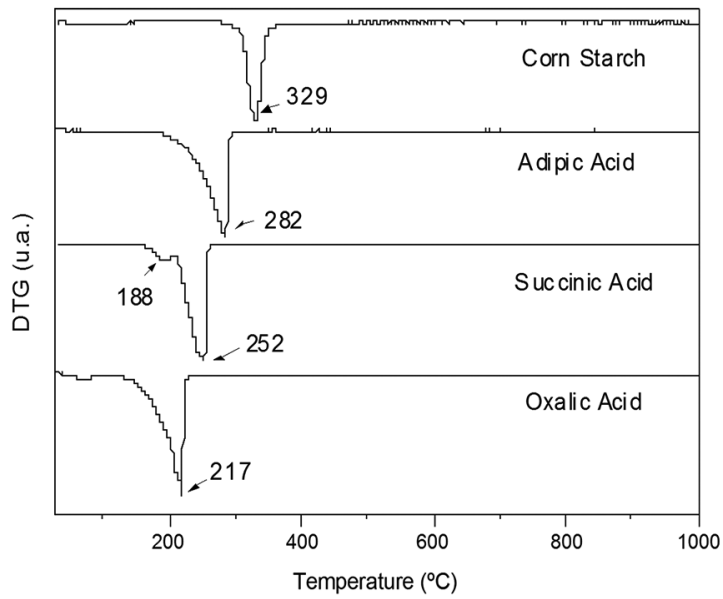

(b)

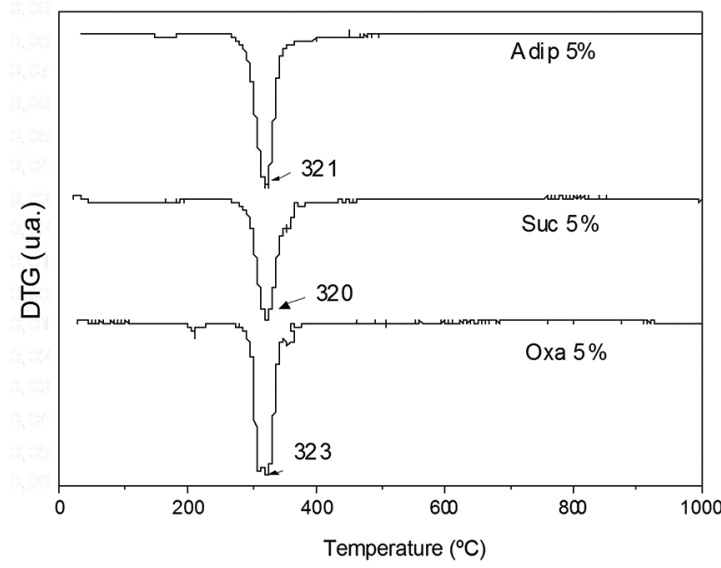

(d)

Figure 1. TG and DTG curves of the precursors and biofilms. 
in the biofilm produced. In Figure 3b, starch presented a semicrystalline profile. The film containing adipic acid also presented a semicrystalline event at $2 \theta=22^{\circ}$, related to the presence of unreacted adipic acid. Films containing oxalic and adipic acid were less crystalline than corn starch. Thus, it is possible to infer that an interaction of these acids with starch may occur. When analyzing the XRD pattern

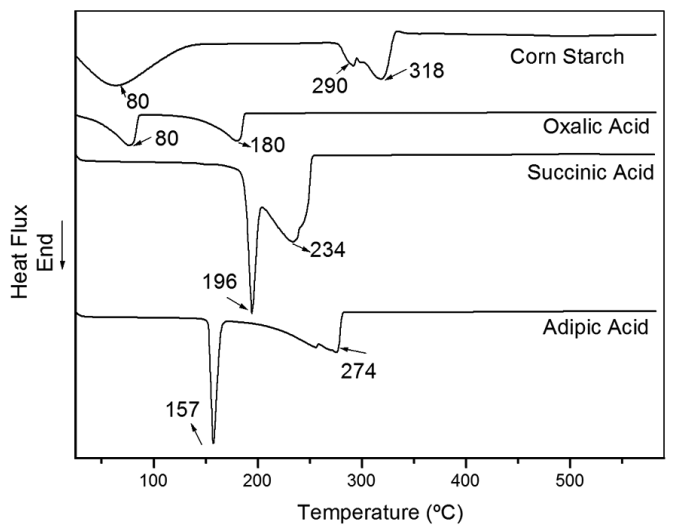

(a)

Figure 2. DSC curves of the precursors (a) and biofilms (b).

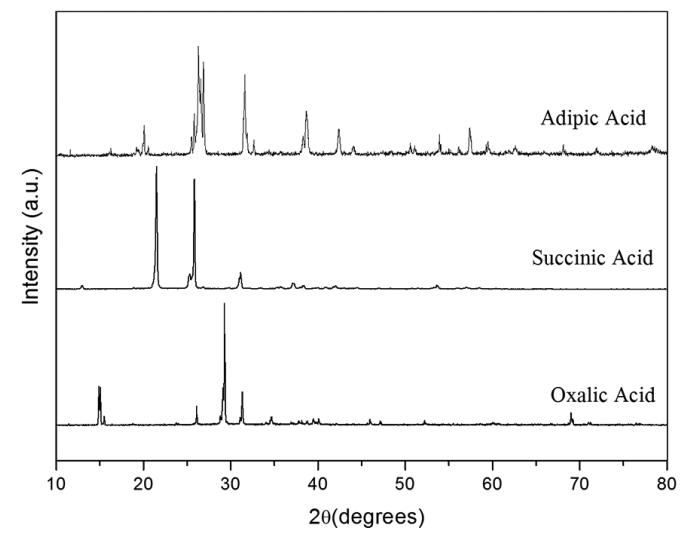

(a)

Figure 3. XRD diffractograms of the precursor (a) and biofilms (b).

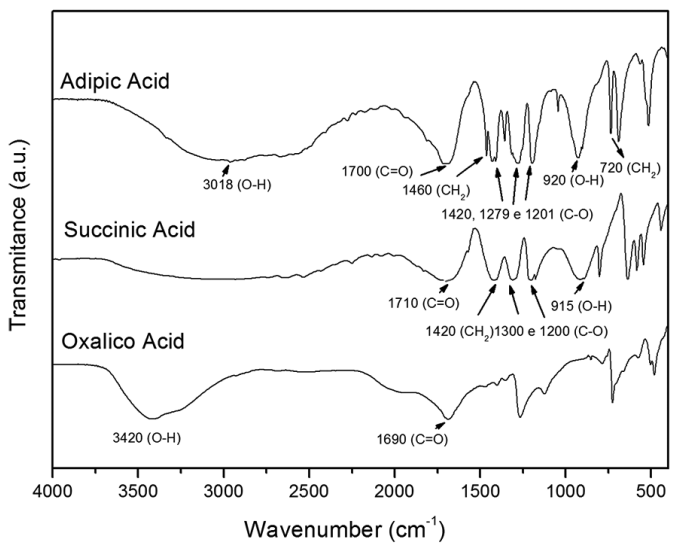

(a) of the film containing succinic acid it was observed a halo, indicating that the material was amorphous. Therefore it can be inferred that succinic acid interacted more significantly with starch in comparison with other acids, these results corroborate the results of the DSC.

Figure 4 shows the spectra obtained from the pure acids and biofilms. In Figure 4a, events characteristic of carboxylic

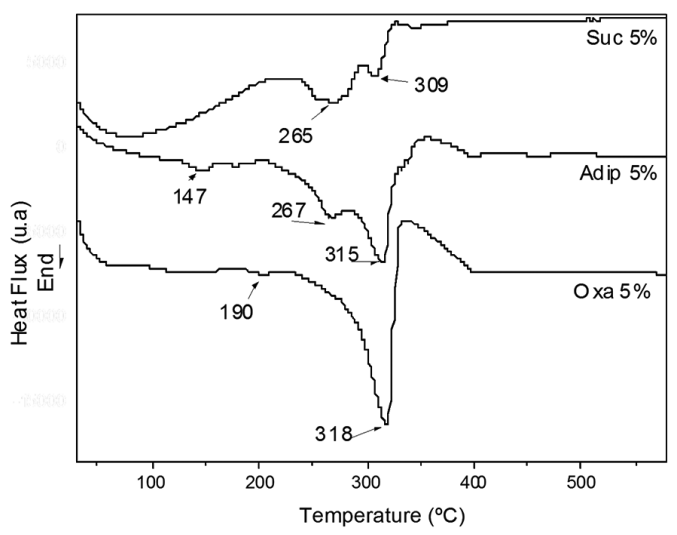

(b)

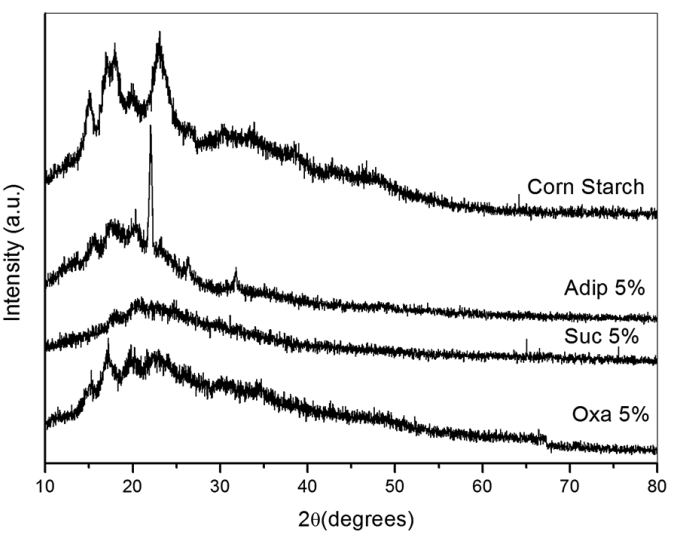

(b)

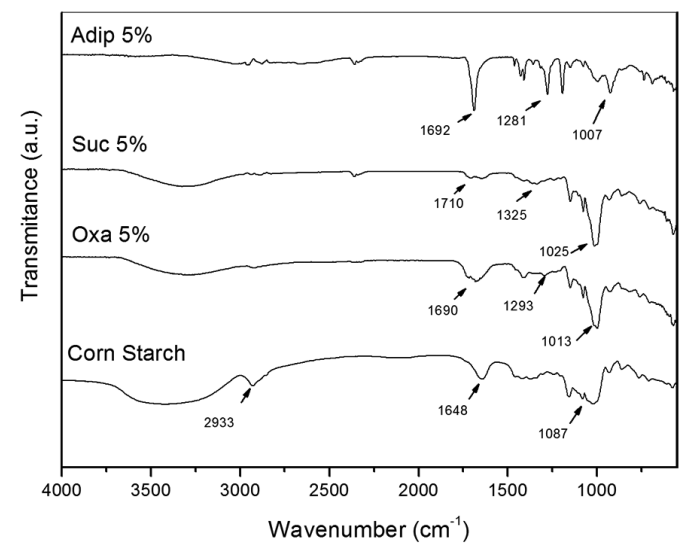

(b)

Figure 4. FTIR spectra of the precursors (a) and biofilms (b). 
acids can be observed: the $3420-3200 \mathrm{~cm}^{-1}$ region refers to $\mathrm{OH}$ bond and the region between 1710 and $1690 \mathrm{~cm}^{-1}$ refer to the $\mathrm{C}=\mathrm{O}$ bond. The events in 1460 and $1420 \mathrm{~cm}^{-1}$, observed in adipic and succinic acid, were attributed to the $\mathrm{CH}_{2}$ grouping. To the adipic acid, the $\mathrm{CH}_{2}$ band also appears in the region of $720 \mathrm{~cm}^{-1}$, because this acid has the unit of repetition $-\left(\mathrm{CH}_{2}\right) \mathrm{n}$ - greater than three. The bands related to $\mathrm{CO}$ bond appear in the regions 1420 and 1300 to $1200 \mathrm{~cm}^{-1}$. In the Figure $4 \mathrm{~b}$ it is possible to verify the spectra of the films and the corn starch. In corn starch there is a band at $2933 \mathrm{~cm}^{-1}$ representing the methyl group of the $\mathrm{CH}$ stretching, a spectrum at $1087 \mathrm{~cm}^{-1}$ related to the stretching of secondary and primary alcohols and another spectrum at $1648 \mathrm{~cm}^{-1}$ related to the presence of water ${ }^{6}$. In all spectra of biofilms a band between 3000 and $3500 \mathrm{~cm}^{-1}$ related to the stretching of $\mathrm{OH}$ bond was observed. The region of 1690-1710 $\mathrm{cm}^{-1}$ is related to the presence of $\mathrm{C}=\mathrm{O}$ of carboxylic acids. To 5\% ADIP, the band was more intense when compared to the other films, confirming the presence of residual acid. The formation of ester, obtained by reaction of the alcohol present in the starch and the carboxylic acid present in the films, was observed in all biofilms and showed two separate ranges: $1300-1250$ and $1200-1050 \mathrm{~cm}^{-1}$.

By analyzing the micrographs of the surface of the films, Figure 5, it is possible to see a more homogeneous surface in the film containing succinic acid. Therefore, these results corroborate the results of other analyzes demonstrating better interaction between the starch and succinic acid.

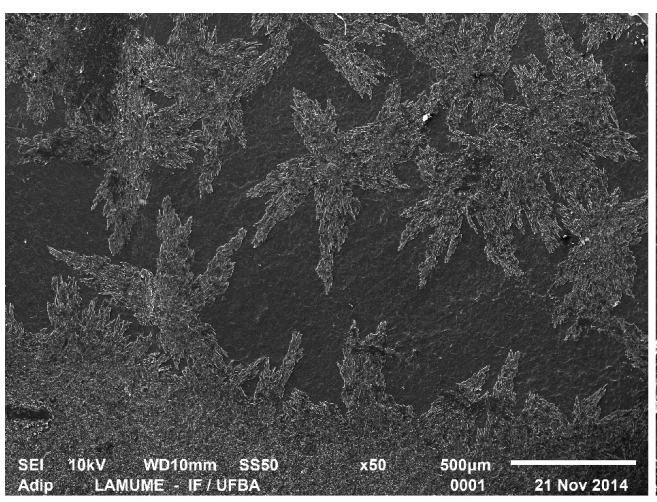

(a)

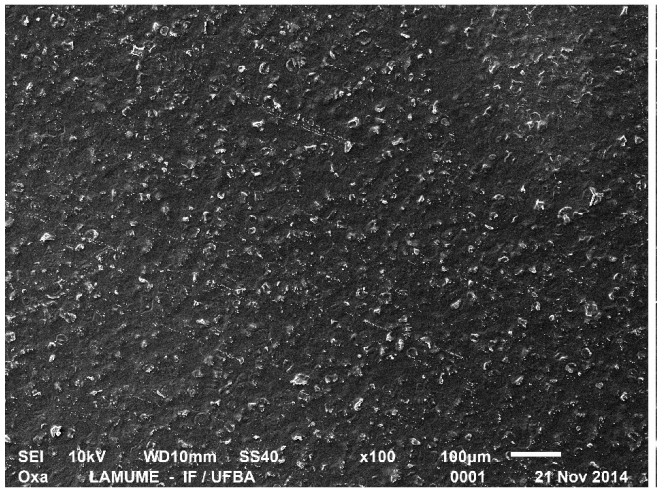

(c)

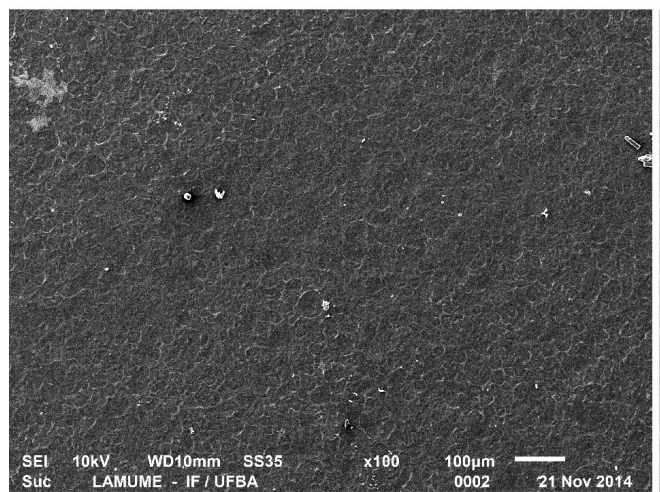

(e)

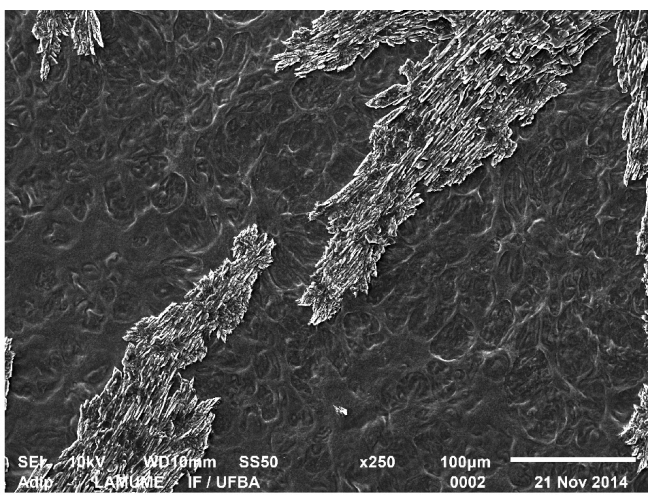

(b)

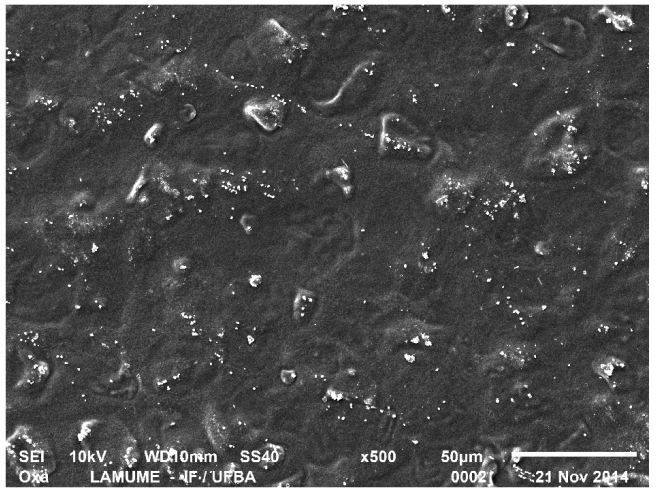

(d)

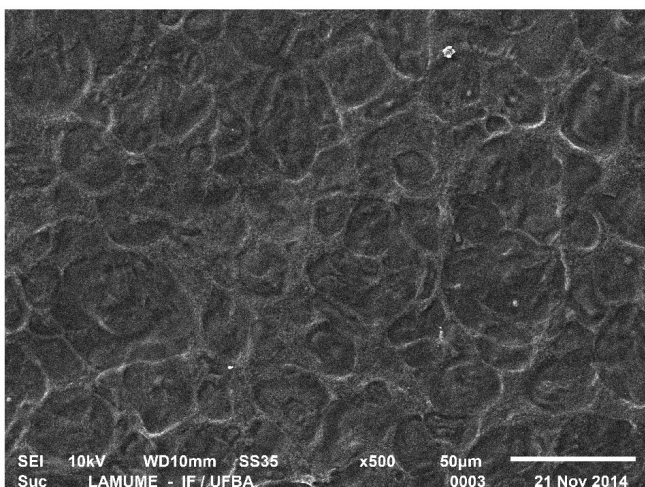

(f)

Figure 5. Scanning electron micrographs of the surface of ADIP 5\% in 50x (a) and 250x (b), OXA 5\% in 100x (c) and 500x (d), SUC 5\% in $100 \mathrm{x}$ (e) and 500x (f). 


\section{Conclusions}

It was possible to obtain films of adipic, succinic and oxalic acids with starch by the casting process. Analyzing the thermal behavior of the films it was observed a greater interaction of succinic acid with starch. The films containing oxalic acid and adipic acid were less crystalline than corn starch. When analyzing the XRD pattern of the film containing succinic acid it was observed a halo indicating an amorphous material. The FTIR spectra showed the formation of ester

\section{References}

1. Sanchez-Garcia MD and Lagaron JM. On the use of plant cellulose nanowhiskers to enhance the barrier properties of polylactic acid. Cellulose. 2010; 17(5):987-1004. http://dx.doi. org/10.1007/s10570-010-9430-x.

2. Averous L and Boquillon N. Biocomposites based on plasticized starch: thermal and mechanical behaviours. Carbohydrate Polymers. 2004; 56(2):111-122. http://dx.doi.org/10.1016/j. carbpol.2003.11.015.

3. Durango AM, Soares NF, Andrade NJ. Extração e caracterização do amido de inhame e desenvolvimento de filmes comestíveis antimicrobianos. Temas Agrários. 2009; 14 (2): 1-18.

4. Kaewtatip K and Thongmee J. Effect of kraft lignin and esterified lignin on the properties of thermoplastic starch. Materials \& Design. 2013; 49:701-704. http://dx.doi.org/10.1016/j. matdes.2013.02.010.

5. Bhat R, Abdullah N, Din RH and Tay GS. Producing novel sago starch based food packaging films by incorporating lignin isolated from oil palm black liquor waste. Journal of Food Engineering. 2013; 119(4):707-713. http://dx.doi.org/10.1016/j. jfoodeng.2013.06.043.

6. Corradini E, Carvalho AJF, Curvelo AAS, Agnelli JAM and Mattoso LHC. Preparation and characterization of thermoplastic starch/zein blends. Materials Research. 2007; 10(3):227-231. http://dx.doi.org/10.1590/S1516-14392007000300002. and thus one can infer a likely interaction of the acid with starch. Therefore, it was shown that the size of the fatty chains influence on the thermal and structural properties of biofilms and that succinic acid was the most reactive with starch.

\section{Acknowledgements}

The authors thank to FAPESB (Foundation for Research of State of Bahia) for financial support and scholarship. C. S. Miranda and J.C. Oliveira thank CAPES for scholarship.

7. Corradini E, Teixeira EM, Agnelli JAM, Mattoso LHC. Amido termoplástico. São Carlos: Embrapa Instrumentação Agropecuária; 2007. p. 1-27. Embrapa Instrumentação: Documentos, 30.

8. Fayad SJ. Efeitos de plastificante e reticulante nas propriedades de filmes formados por caseína e gelatina. [Dissertation]. Florianópolis: University Federal of Santa Catarina; 2007.

9. Sothornvit R and Krochta JM. Plasticizer effect on mechanical properties of $\beta$-lactoglobulin films. Journal of Food Engineering. 2001; 50(3):149-155. http://dx.doi.org/10.1016/S02608774(00)00237-5.

10. Fiorucci AR, Soares MH, Cavalheiro ETG. Ácidos orgânicos: dos primórdios da química experimental à sua presença em nosso cotidiano. Química Nova na Escola. 2002; 15: 6-10.

11. Ramírez MG. Desenvolvimento de biocompósitos de amido termoplástico reforçados por fibra de coco verde. [Thesis]. Curitiba: Instituto de Ciências Agrárias, Universidade Federal do Paraná; 2005.

12. Brioude MM, Guimarães DH, Fiúza RP, Prado LASA, Boaventura JS and José NM. Synthesis and characterization of aliphatic polyesters from glycerol, by-product of biodiesel production, and adipic acid. Materials Research. 2007; 10(4):335-339. http://dx.doi.org/10.1590/S1516-14392007000400003.

13. Spiridon I, Teaca CA and Bodirlau R. Preparation and characterization of adipic acid-modified starch microparticles/ plasticized starch composite films reinforced by lignin. Journal of Materials Science. 2011; 46(10):3241-3251. http://dx.doi. org/10.1007/s10853-010-5210-0. 